\title{
RESEARCH
}

Open Access

\section{Compatibility of some botanicals and the entomopathogenic fungus, Beauveria bassiana (Bals.), against the red flour beetle, Tribolium castaneum (Herbst) (Coleoptera: Tenebrionidae)}

\author{
Habib-ur Rehman ${ }^{1 *}$ (D, Amer Rasul ${ }^{1}$, Muhammad Aslam Farooqi ${ }^{2^{*}}$, Hafiz Muhammad Usman Aslam³,
} Beenish Majeed ${ }^{4}$, Muhammad Sagheer ${ }^{1}$ and Qurban $\mathrm{Ali}^{5}$

\begin{abstract}
Background: The red flour beetle, Tribolium castaneum (Herbst) (Coleoptera: Tenebrionidae), is a serious pest of stored grain commodities worldwide which results in considerable losses to stored wheat, Triticum aestivum (Linn.).

Main body: The present laboratory bioassay was carried out to examine the efficiency of the fungus, Beauveria bassiana (Bals.) formulation (Racer ${ }^{\mathrm{TM}}$ ), and Neem extract (NE), Eucalyptus extract (EE), and Tobacco extract (TE) against 3rd instar larvae of T. castaneum. The fungal formulation was applied at $0.3 \times 10^{8}, 0.6 \times 10^{8}$, and $0.9 \times 10^{8} \mathrm{conidia} \mathrm{kg}^{-1}$ of the crushed wheat grains; as well, it was mixed separately with $5 \%$ concentrations of each plant extract under the laboratory conditions of $30 \pm 2{ }^{\circ} \mathrm{C}$ and $65 \pm 5 \% \mathrm{RH}$. Mortality rate of the tested larvae was enumerated after regular intervals of times. Mortality of the larvae increased at the highest combined concentrations of the fungal conidial formulation and the plant extracts rather than their single treatments. The highest mortality rate of the larvae (71.32\%) was recorded at the highest concentration binary mixture of (Racer ${ }^{\mathrm{TM}}+\mathrm{NE}$ ), whereas relatively the lowest mortality rate (15.54\%) was enumerated in the combined treatments of (Racer ${ }^{\mathrm{TM}}+\mathrm{NE}$ ). Furthermore, the highest separate concentration of B. bassiana $\left(0.9 \times 10^{8}\right.$ conidia/ml) persistently resulted in more larval mortality $(32.68 \%)$ of 3 rd instar larvae of $T$. castaneum than the plant extracts $(7.52,9.89$, and $14.61 \%)$, respectively. A noticeably greater rate of mycosis and sporulation was counted in the larvae of the insect in separate treatments of $B$. bassiana than in its combined applications with the plant extracts. The highest mycosis (85.13\%) and sporulation (160.12 conidia/ml) was detected in the treatment, where the lowest concentration of $B$. bassiana $\left(0.3 \times 10^{8}\right.$ conidia/ml) was used, alone.

Conclusion: Hence, it was concluded that integrated use of these two bio-pesticides plus the fungus can be helpful in the integrated pest management program of T. castaneum.
\end{abstract}

Keywords: Tribolium castaneum, Beauveria bassiana, Eucalyptus, Neem, Mortality, Sporulation

\footnotetext{
*Correspondence: habib.ento@gmail.com; aslam_faroogi1770@yahoo.com

'Department of Entomology, University of Agriculture, Faisalabad, Pakistan

${ }^{2}$ Department of Entomology, The Islamia University of Bahawalpur,

Bahawalpur, Pakistan

Full list of author information is available at the end of the article
}

\section{Springer Open}

(c) The Author(s). 2020 Open Access This article is licensed under a Creative Commons Attribution 4.0 International License, which permits use, sharing, adaptation, distribution and reproduction in any medium or format, as long as you give appropriate credit to the original author(s) and the source, provide a link to the Creative Commons licence, and indicate if changes were made. The images or other third party material in this article are included in the article's Creative Commons licence, unless indicated otherwise in a credit line to the material. If material is not included in the article's Creative Commons licence and your intended use is not permitted by statutory regulation or exceeds the permitted use, you will need to obtain permission directly from the copyright holder. To view a copy of this licence, visit http://creativecommons.org/licenses/by/4.0/. 


\section{Background}

Stored grains commodities are vulnerable to be attacked by numerous insect pests. Among them, the red Flour beetle, Tribolium castaneum (Herbst) (Coleoptera: Tenebrionidae), is known as main insect pest of stored agricultural cereals and wheat flour worldwide (Buckman et al. 2013). Larval and adult stages of T. castaneum feed on damaged grains by other stored grain insects (Sarwar 2015). It is a polyphagous insect pest and typically attacks the stored broken wheat grains, wheat flour, and other grinded cereals (Bosly and Kawanna 2012). The pest adults are very energetic and capable to complete their growth even in less food reserves (Campbell and Runnion 2003).

Control of stored commodities insect pests is typically carried out by traditional synthetic insecticides (Athanassiou and Palyvos 2006). In a number of countries, control of stored commodities insect pests is mostly accomplished by grain fumigants (Zettler and Arthur 2000). Fumigation by phosphine is the main approach for the operative control of the insect pests (Chadda 2016). But the application of phosphine fumigation has become restricted as some stored products insect pests like Trogoderma granarium Everts have developed resistance against it (Pimentel et al. 2010). To combat the resistance issues in stored grain insect pests, there is utmost desire to move substitute strategies of stored grain insect pest management which are environment-friendly, cast effective, and socially appropriate (Nboyine et al. 2015).

Application of plant-derived materials (i.e., plants powders, extracts, oils) as fumigants for the control of stored commodities insect pests and their products is potential substitute approach for the control of insect pests (Rehman et al. 2018). The plant extracts are operative fumigants and have no hazardous effects to human and animals health (Rajendran and Sriranjini 2008) and are also biodegradable (Negahban et al. 2007). Numerous plants have now been defined for their toxicological properties of which Azadirachta indica (A. juss.) is a promising one (Asawalam et al. 2007). The leaf extract of Azadirachtin indica has been operative for the stored commodities' insect pests mainly for the environment-friendly control of $T$. castaneum (Islam and Talukder 2005). The extract of Datura inoxia (Mill.) and A. indica proved effective against different stored grains' insect pests (Ali et al. 2017). Nicotiana tabacum along with $A$. indica have been found effective against T. castaneum (Hanif et al. 2016).

Entomopathogenic fungi (EPF) are a specialized group of fungi comprising of numerous genotypes (Araújo and Hughes 2016). Owing to a great stress on application of bio-control for the environment pleasant control of stored commodities insect pests and field crops, the EPF have gained huge consideration in recent few years (Hyde et al. 2019). Beauveria bassiana (Bals.) Vuillemin (Hypocreales: Clavicipitaceae) has been extensively studied in this respect. Efficacy of EPF highly depends upon ambient moisture (Lord 2007). The effect of moisture on effectiveness of $B$. bassiana against insect pests has been found to range from no effect to a straight correlation between efficacy and ambient moisture (Haraprasad et al. 2001).

The present research worked on evaluating the efficacy of three plant extracts and $B$. bassiana against $T$. castaneum under laboratory conditions.

\section{Main text}

\section{Materials and methods}

Studies were carried out at the Grain Research, Training and Storage Management Cell, Department of Entomology, University of Agriculture Faisalabad, Pakistan.

\section{Collection and rearing of test insects}

Tribolium castaneum adults of mixed age were collected from different grain markets situated in the district of Faisalabad, Punjab province, Pakistan. The insect population was brought back to the laboratory and sustained at sterilized plastic jars placed in an incubator at $30 \pm 2{ }^{\circ} \mathrm{C}$ and $65 \pm 5 \% \mathrm{RH}$ according to process stated by Ali et al. (2012). Sterilized crushed wheat grains were used for the mass rearing of T. castaneum. Adults of the tested insect pest were released on fresh, sterilized wheat grains $(800 \mathrm{~g})$ for the purpose of egg-laying. Jars were concealed by muslin cloth for ventilation and tighten up with rubber bands to avoid the insects' escape. To get the first homogenous generation $\left(F_{1}\right)$, pupae of the identical age were collected on day-to-day basis in separate plastic jars having preferred diet of the target insect. The 3rd instar larvae of the test insect were used for further bioassays.

\section{Source of bio insecticides}

Formulation (Racer ${ }^{\mathrm{TM}}$ ) of the EPF, Beauveria bassiana ( $1 \mathrm{~g}$ of Racer $^{\mathrm{TM}}$ containing $10^{8}$ conidia) was acquired from Agri Life, Medak District. Hyderabad, India. Leaves of neem (Azadirachta indica), eucalyptus (Eucalyptus globulus), and tobacco (Nicotiana tabacum) were collected from different localities in University of Agriculture Faisalabad, Pakistan.

\section{Extraction of plant materials}

Plant leaves were cleaned by distilled water and placed in shade for drying. Dried plant leaves were then ground in an electrical grinder (Mamba $1 / 16 \mathrm{oz}$, USA Patanasetagit Company Ltd.) to create a powdered form. Extracts were prepared by using a Rotatory shaker (IRMECO, OS 10) by immersing $50 \mathrm{~g}$ of each plant powder separately in $250 \mathrm{ml}$ acetone in conical flasks, according to the process elaborated by Ahmad et al. (2006). Solvent from the crude extracts was evaporated by a rotary evaporator (Hei-VAP, Heidolph, Germany) and stored in a refrigerator at $4{ }^{\circ} \mathrm{C}$ before use. 


\section{Bioassay studies}

Mortality rates of $T$. castaneum larvae were checked, using Whatman filter papers (diam. $125 \mathrm{~mm}$ ). Filter papers were treated distinctly with $5 \%$ concentrations of every plant extract and permitted to get dry before starting the bioassay. Treated filter papers were transferred into Petri-dishes. One Petri-dish was kept as a control for each treatment containing untreated diet. Thirty larvae of $3 \mathrm{rd}$ instar of $T$. castaneum were released in each Petri-dish containing crushed wheat grains and covered with perforated lids. Three replications for each treatment were used. Larval mortality data was recorded periodically. B. bassiana formulation ( $\operatorname{Racer}^{\mathrm{TM}}$ ) was applied at three concentrations of $0.3 \times 10^{8}, 0.6 \times 10^{8}$, and $0.9 \times 10^{8}$ conidia/ $/ \mathrm{kg}$ of wheat grains against T. castaneum (Khashaveh et al. 2011). The sterilized food was treated with each concentration rate of entomopathogenic fungi and fed to target insect pests. Samples of $50 \mathrm{~g}$ of treated commodity for each concentration rate were placed into 3 separate sterilized small plastic jars (replicates). Three jars with untreated food were used as control. Data regarding larval mortality was recorded periodically (Kavallieratos et al. 2006).

\section{Combined effects of the plant extracts and Beauveria bassiana against Tribolium castaneum}

The conidia of $B$. bassiana ( Racer $^{\mathrm{TM}}$ ) were mixed with wheat grains at rates of $0.3 \times 10^{8}, 0.6 \times 10^{8}$, and $0.9 \times$ $10^{8}$ conidia $/ \mathrm{kg}$ of crushed wheat grains. Three lots of 50 $\mathrm{g}$ from each of the fungal conidia treated diet were transferred into separate small plastic jars and sprayed with $5 \%$ of the 3 plant extracts. The treated grains were placed into small plastic jars. Thirty larvae (3rd instar) of the tested insect pest were released in each small plastic jar containing treated diet. Three replications were used. Data regarding mortality and growth inhibition were recorded after regular intervals.

\section{Mycosis and sporulation}

Cadavers of $T$. castaneum were collected from the fungal treated experimental units, positioned on a disinfected Petri dish, and refrigerated at $4{ }^{\circ} \mathrm{C}$ in small vials. Later on, all the cadavers were superficial decontaminated by $0.05 \%$ sodium hypochlorite solution for a period of $2-3$ min trailed by $2-3$ washing through distilled water. Afterwards, cadavers were positioned on Potato Dextrose Agar (PDA) Petri-dishes and incubated at $26 \pm$ $1{ }^{\circ} \mathrm{C} ; 75 \pm 5 \% \mathrm{RH}$ for 7 days. The insect cadavers displaying the outer fungal growth were witnessed under the microscope. For checking the sporulation, the mycosed insect cadavers from every replication were mixed in 20$\mathrm{ml}$ distilled water by a drop of Tween- 80 and blended for $10 \mathrm{~min}$. The whole quantity of conidia/ml was counted by means of the hemocytometer under microscope (Riasat et al. 2011).

\section{Statistical analysis}

After the completion of all bioassays, corrected mortality of recorded data was calculated using Abbott's formula (Abbott 1925):

$$
\text { Corrected mortality }(\%)=\frac{\operatorname{Mo}(\%)-\mathrm{Mc}(\%)}{100-\operatorname{Mc}(\%)} \times 100
$$

where:

Mo $=$ observed mortality

Mc $=$ mortality in control

The data of $\%$ corrected larval mortality and other treatments and their combinations were statistically analyzed by using STATISTICA 8 software, and significant treatment findings were compared by Tuckey-HSD test. The percent pupae and adult inhibitions were calculated as:

$$
\begin{aligned}
& \text { \%Pupae inhibition or Adult inhibition } \\
& \quad=100 *(1-t / c)
\end{aligned}
$$

where $t$ is number of pupae or adult in treated grains and $c$ is pupae or adult present in control.

\section{Results and discussion \\ Mortality rates of $T$. castaneum larvae}

Statistically remarkable differences were noticed in the larval mortality of 3 rd instar larvae of $T$. castaneum when exposed to a separate or joint treatments of the plant extracts and $B$. bassiana $(B b)$. Furthermore, the bio-assayed instar (3rd instar) of T. castaneum displayed higher percent mortality of combined use of both types of treatments than their separate uses (Table 1). The highest larval mortality of 3rd instar larvae (71.32\%) was recorded in the treatment combination that has maximum concentration of B. bassiana $\left(0.9 \times 10^{8}\right.$ conidia/ $\mathrm{ml}$ ) and Neem extract (5\%). Furthermore, the highest separate concentration of $B$. bassiana $\left(0.9 \times 10^{8}\right.$ conidia/ $\mathrm{ml}$ ) persistently resulted in more larval mortality (32.68\%) of 3rd instar larvae of T. castaneum than the neem $(7.52 \%)$, eucalyptus (9.89\%), and tobacco extracts (14.61\%). Regarding the pupae and adult inhibition, a remarkable decrease in pupation and adult appearance was detected in bio-assayed 3rd instar larvae of $T$. castaneum when exposed to joint applications of B. bassiana + the plant extracts than in their separate uses (Table 1). The lowest pupation and adult emergence (9.71 and 4.89\%) was recorded in treatment where maximum concentration of the $B$. bassiana $\left(0.9 \times 10^{8}\right.$ conidia $\left./ \mathrm{ml}\right)$ was used along with NE. Though the highest pupation and adult inhibition (52.87 and $44.20 \%$, respectively) of the $T$. castaneum larvae were noticed in the treatment where the lowest separate fungal concentration $(0.3 \times$ $10^{8}$ conidia $/ \mathrm{ml}$ ) was used, generally, the highest pupation and adult emergence were recorded in the treatments with the lowest larval mortality (Table 1). 
Table 1 Effect of Beauveria bassiana (Bb) and plant extracts on mortality, pupation, and adult emergence (\% \pm SE) of 3rd larval instars of Tribolium castaneum

\begin{tabular}{|c|c|c|c|}
\hline Treatments & Mortality (\%) & Pupae inhibition (\%) & Adult inhibition (\%) \\
\hline B1 & $21.29 \pm 2.18 \mathrm{~g}$ & $52.87 \pm 1.49 c$ & $44.20 \pm 1.23 b$ \\
\hline B2 & $26.47 \pm 2.50 \mathrm{~g}$ & $34.43 \pm 2.22 f$ & $31.90 \pm 0.93 d$ \\
\hline B3 & $32.68 \pm 3.26 f$ & $28.75 \pm 2.20 \mathrm{~h}$ & $25.13 \pm 1.11 d$ \\
\hline TE & $7.521 .73 i$ & $42.12 \pm 2.52 d$ & $39.41 \pm 2.83 c$ \\
\hline $\mathrm{EE}$ & $9.89 \pm 2.30 \mathrm{hi}$ & $40.04 \pm 1.89 e$ & $36.96 \pm 1.34 c$ \\
\hline NE & $14.61 \pm 3.22 \mathrm{~h}$ & $35.10 \pm 2.62 f$ & $30.58 \pm 1.63 \mathrm{de}$ \\
\hline $\mathrm{B} 1 \times \mathrm{TE}$ & $15.54 \pm 1.12 \mathrm{~h}$ & $39.62 \pm 2.42 \mathrm{~g}$ & $31.08 \pm 1.63 f$ \\
\hline $\mathrm{B} 1 \times \mathrm{EE}$ & $22.18 \pm 2.61 \mathrm{~g}$ & $33.14 \pm 1.92 f$ & $30.08 \pm 2.23 \mathrm{de}$ \\
\hline $\mathrm{B} 1 \times \mathrm{NE}$ & $31.15 \pm 3.62 f$ & $29.32 \pm 2.79 f$ & $26.08 \pm 2.50 d$ \\
\hline $\mathrm{B} 2 \times \mathrm{TE}$ & $38.87 \pm 2.93 \mathrm{e}$ & $25.51 \pm 2.54 \mathrm{e}$ & $22.78 \pm 1.66 c$ \\
\hline $\mathrm{B} 2 \times \mathrm{EE}$ & $40.05 \pm 1.11 d$ & $30.19 \pm 1.85 h$ & $26.19 \pm 1.79 f$ \\
\hline $\mathrm{B} 2 \times \mathrm{NE}$ & $46.17 \pm 1.92 \mathrm{C}$ & $23.65 \pm 1.67 \mathrm{~g}$ & $19.34 \pm 1.39 e$ \\
\hline $\mathrm{B} 3 \times \mathrm{TE}$ & $50.23 \pm 1.19 c$ & $17.10 \pm 1.92 d$ & $18.13 \pm 2.13 b c$ \\
\hline $\mathrm{B} 3 \times \mathrm{EE}$ & $60.35 \pm 1.33 b$ & $13.10 \pm 1.92 d$ & $10.13 \pm 2.13 b c$ \\
\hline $\mathrm{B} 3 \times \mathrm{NE}$ & $71.32 \pm 1.33 a$ & $9.71 \pm 2.23 b$ & $4.89 \pm 2.63 b$ \\
\hline \multirow[t]{2}{*}{ Control } & - & $69.81 \pm 1.98 a$ & $61.10 \pm 2.10 a$ \\
\hline & $F=234.81, d f=16$ & $F=81.52 \mathrm{df}=16$ & $F=10.34, d f=16$ \\
\hline
\end{tabular}

$B 10.3 \times 10^{8}$ conidia, $B 20.6 \times 10^{8}$ conidia, B3 $0.9 \times 10^{8}$ conidia, $T E$ tobacco extract, EE eucalyptus extract, NE neem extract.The lettering (a-g) shown that treatment means having similar letterings are not significantly different from each other

In previous studies, many researchers have shown that botanicals and EPF have entomocidal and growth inhibition effects against stored grain insect pests. As such, 3rd instar larvae of T. castaneum L. displayed somewhat dissimilar developmental and demise reactions to the insect control agents practiced in the presented research work. A considerable greater mortality rate was detected in the 3rd instar larvae against joint use of $B b$ and PE than their separated applications. In previous studies, joint effect of synthetic insecticides at their sub-lethal concentrations with $B$. bassiana caused an enhanced effectiveness of insect pest control strategies by synergism (Purwar and Sachan 2006). Besides the insecticides, the efficiency of EPF have been examined with plant extracts. Combined application of B. bassiana and plant essential oils has resulted in enhanced control of the $T$. castaneum larvae (Akbar et al. 2005). Wraight and Ramos (2005) noticed that combined use of B. bassiana and $B t$ resulted from greater larval death of Leptinotarsa decemlineata S. than their individual applications.

The improved synergistic outcome of the EPF and PE used in this research could be owing to the reality that feeding deterrence impacts of plant extracts induced starvation stress in the insects, which augmented growth period of the T. castaneum larvae and amplified their vulnerability to fungal invasion and multiplication because of extended inter molt times. The findings are consistent with Furlong and Groden (2003) who stated that starvation pressure augmented the B. bassiana infection against the grubs of Leptinotarsa decemlineata (Say). The plants extracts detained the diet of insects, whereas the fungal spores quickly kill the debilitated larvae. Ali et al. (2018) checked the combined effects of botanicals and EPF against stored grains insects and noticed the combined applications resulted in greater mortality of Sitobion avenae (Fab.) than alone applications. Castiglioni et al. (2003) noticed that the combined application of the neem extracts and B. bassiana gave better results in controlling stored commodities insect pests like outcomes of this research. The compatibility of the botanicals and EPF varied among different species of the fungi. Furthermore, it also depends upon the presence of different types of the plant secondary metabolites in the extracts.

The efficacy of B. bassiana ( $\operatorname{Racer}^{\mathrm{TM}}$ ) was straightly connected to the temperature and RH (Lord 2007). The less mortality rates of the target larvae after the use of $B$. bassiana were attributed to the temperature practiced in the present study. This is in line with Vassilakos et al. (2006) who noticed greater effectiveness of B. bassiana at $26^{\circ} \mathrm{C}$ than at $30^{\circ} \mathrm{C}$. Obtained outcomes were in consistent with Khashaveh et al. (2011) who examined the exposure period and concentration depended impact of B. bassiana for Sitophilus granarius (L.), Oyzophilus surinamens (L.), and T. castaneum. The findings of the presented study at low concentration of $B$. bassiana were in line with Akbar et al. (2004) who applied a formulation 


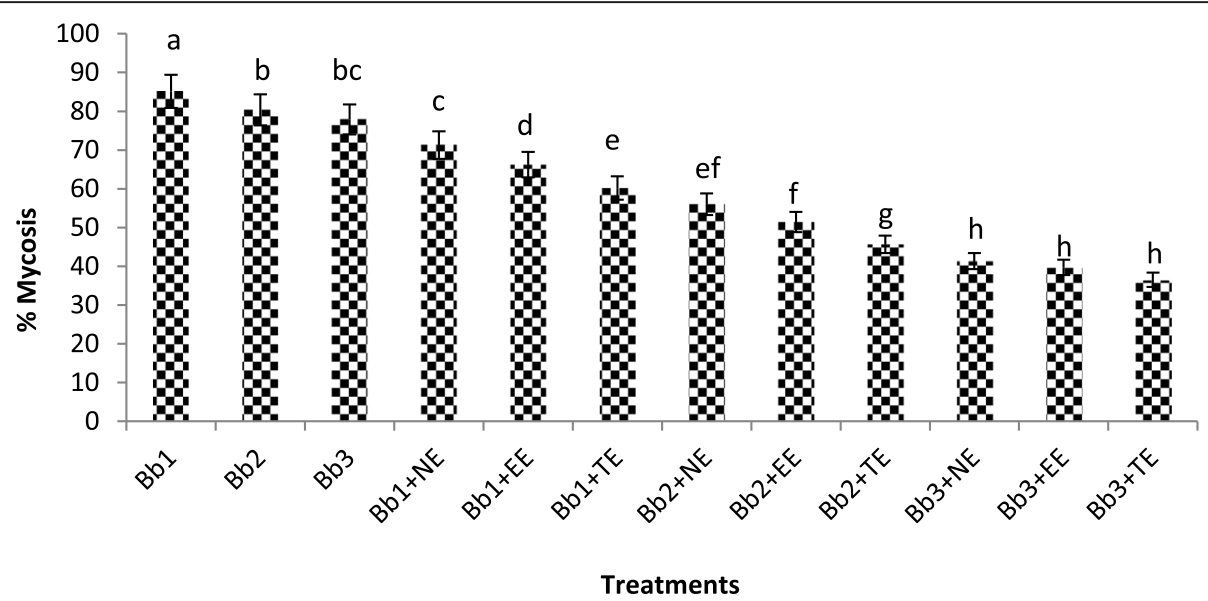

Fig. 1 Impact of the plant extracts and Beauveria bassiana (Bb) concentrations on (\%) mycosis in cadavers of 3rd instars larvae of Tribolium castaneum. Bars with the same letters are not significantly different at $5 \%$ significance level. Vertical bars reflect standard error (SE). Where the value of $\mathrm{Bb} 1$ is $0.3 \times 10^{8}$ conidia $/ \mathrm{ml}, \mathrm{Bb} 2$ is $0.6 \times 10^{8}$ conidia $/ \mathrm{ml}$ and $\mathrm{Bb} 3,0.9 \times 10^{8}$ conidia $/ \mathrm{ml}(F$ cal. $=7.65$, df $=11$, and $P<0.05)$

of B. bassiana (containing $9.4 \times 10^{10}$ conidia per $2000-\mathrm{g}$ wheat grains) against the T. castaneum. The outcomes are in agreement with the results of Inglis et al. (2001), who described that dissimilar developmental phases of insects differ in their vulnerability to fungal contagion. It has been specified the detoxication activity of enzymes variations expressively inside and among dissimilar growth phases of insects. This enzymatic activity is negligible in egg phase, intensifies by every larval phase, and then again decreases to the minimum level at pupal phase (Mullin 1988).

\section{Mycosis and sporulation}

Applied treatments affected the mycosis and sporulation in the cadavers of 3rd instar larvae of T. castaneum. A considerably high rate of mycosis and sporulation was enumerated in the larvae of the insect when they were exposed to separate treatments of B. bassiana than the combined applications with the plant extracts. The highest mycosis (85.13\%) and sporulation (160.12 conidia $/ \mathrm{ml}$ ) were detected in the treatments where the lowest concentration of B. bassiana $\left(0.3 \times 10^{8}\right.$ conidia/ $\mathrm{ml}$ ) was used, alone. Contradictory to dose effect for larval mortality, the maximum fungal concentration resulted in the lowest mycosis and sporulation in the 3rd instar larvae of T. castaneum (Figs. 1 and 2).

The tenacity of a fungal insecticide in an agroecosystem relies not merely on its inoculum but also depends to some extent on the later on contagion from mycosed cadavers (Wood and Thomas 1996). In the present research, percent mycosis and sporulation attained the highest peak in treatment where unaccompanied B. bassiana was used at its low concentration. These findings were supported by Tefera and Pringle (2003), who described augmented percent mycosis and sporulation in lepidopteron larvae cadavers infected by least conidial concentration of $B$. bassiana than to its great application rates. Likewise, Riasat et al. (2011) also

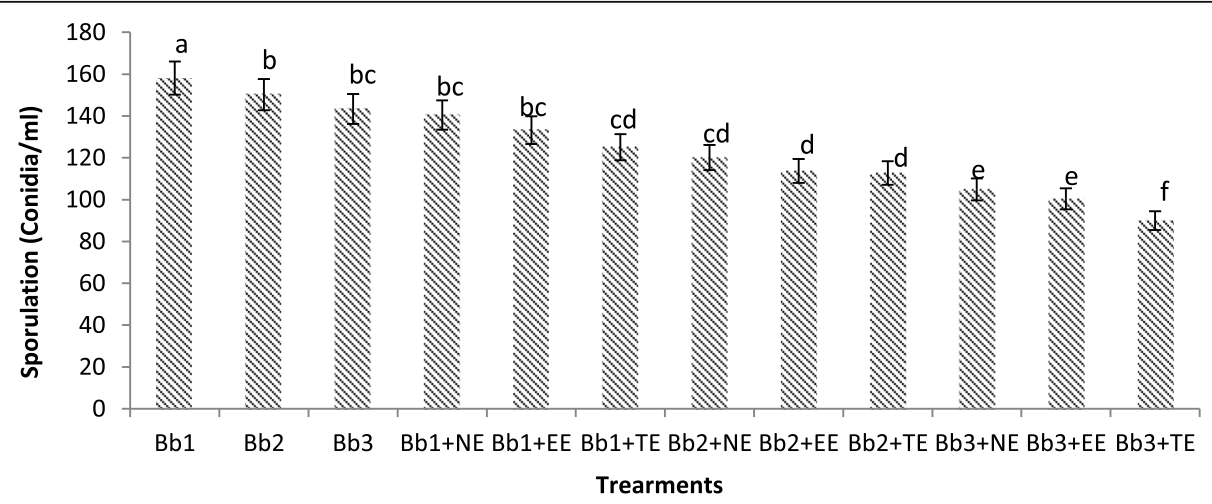

Fig. 2 Impact of the plant extracts and Beauveria bassiana (Bb) concentrations on sporulation in cadavers of 3rd instars larvae of Tribolium castaneum. Bars with the same letters are not significantly different at $5 \%$ significance level. Vertical bars reflect SE. Bb1, $0.3 \times 10^{8} \mathrm{conidia} / \mathrm{ml}$; Bb2, $0.6 \times 10^{8}$ conidia $/ \mathrm{ml} ; \mathrm{Bb} 3,0.9 \times 10^{8}$ conidia $/ \mathrm{ml}$ ( F cal. $=4.43$, df $=11$, and $\left.P<0.05\right)$ 
noticed a great mycosis and sporulation in the Rhyzopertha dominica $\mathrm{F}$. cadavers at application of less $B$. bassiana conidia. The least percent mycosis and sporulation at increased conidial concentrations can be credited to the self-inhibiting process of fungal conidia at great concentrations (Tefera and Pringle 2003).

\section{Conclusion}

Results showed that binary mixtures of botanicals, especially neem extract and B. bassiana, could be an economical approach for the control $T$. castaneum population. The tactic of joint uses of the plant materials and EPF assurances delivering improved efficiency than the efforts to combat the insect pest infestation with individually used treatments.

\section{Abbreviations}

NE: Neem extract; EE: Eucalyptus extract; TE: Tobacco extract; Racer $^{\text {TM}}$ : Trade name of Beauveria bassiana formulation; $\mathrm{RH}$ : Relative humidity; IPM: Integrated pest management; ml: Milliliter; EP: Entomopathogenic; $F_{1}$ : First homogenous generation; g: Grams; PDA: Potato Dextrose Agar; Mo: Observed mortality; Mc: Mortality in Control; $t$ : Number of pupae or adult in treated wheat grains; $\mathrm{C}$ : Pupae or adult present in control; Bb: Beauveria bassiana; B1: $0.3 \times 10^{8}$ conidia; B2: $0.6 \times 10^{8}$ conidia; B3: $0.9 \times$ $10^{8}$ conidia; $L_{50}$ : Lethal concentration required to kill $50 \%$ insect population

\section{Acknowledgements}

The authors highly acknowledged Professor Dr. Linda J Mason, from Purdue University, west Indiana, USA, for review and her valuable comments for this article.

\section{Authors' contributions}

$H R$, MS, and MAF designed the experiment. HR and BM conducted the experiment and wrote the article. AR and QA helped in the statistical analysis. MAF and HUA revised the article. All authors approved the final article after reading.

\section{Funding}

The study was conducted with the available laboratory resources without any aid from any funding agency.

\section{Availability of data and materials}

All data of the study have been presented in the manuscript, and high quality and grade materials were used in this study.

\section{Ethics approval and consent to participate}

Not applicable

\section{Consent for publication}

Not Applicable

\section{Competing interests}

The authors declare that they have no competing interests.

\section{Author details}

${ }^{1}$ Department of Entomology, University of Agriculture, Faisalabad, Pakistan.

Department of Entomology, The Islamia University of Bahawalpur, Bahawalpur, Pakistan. ${ }^{3}$ Department of Plant Pathology, University of Agriculture, Faisalabad, Pakistan. ${ }^{4}$ Department of Chemistry, Government College University, Faisalabad, Pakistan. ${ }^{5}$ Entomological Research Institute, Ayub Agricultural Research Institute, Faisalabad, Pakistan.
Received: 18 May 2020 Accepted: 7 October 2020

Published online: 20 October 2020

\section{References}

Abbott WS (1925) A method for computing the effectiveness of an insecticide. J Econ Entomol 18:265-267

Ahmad UAM, Zuha S, Nabil HH, Bashier HH, Muafi K, Zhongping H, Youling G (2006) Evaluation of Insecticidal Potentialities of Aqueous Extracts from Calotropis procera Ait. against Henosepilachna elaterii Rossi. J Appl Sci 6:2466-2470

Akbar W, Lord CJ, Nechols JR, Loughin TM (2005) Efficacy of Beauveria bassiana for Red Flour Beetle when applied with Plant Essential Oils or in Mineral Oil and Organosilicone Carriers. J Econ Entomol 98:683-688

Akbar W, Lord JC, Nechols JR, Howard RW (2004) Diatomaceous earth increases the efficacy of Beauveria bassiana against Tribolium castaneum larvae and increases conidia attachment. J Econ Entomol 97:273-280

Ali A, Ahmad F, Biondi A, Wang Y, Desneux N (2012) Potential for using Datura alba leaf extracts against two major stored grains pests, the rice weevil Sitophillus oryzae and Khapra beetle Trogoderma granarium. J Pest Sci 3:359-366

Ali K, Saghee M, Hasan M, Rashid A (2017) Impact of extracts of Azadirachta indica and Datura inoxia on the esterases and phosphatases of three stored grains insect pests of economic importance. Pak J Agri Sci 1:71-81

Ali S, Farooqi MA, Ullah MI, Qureshi AK, Siddique B, Waheed W, Sarfraz M, Asghar A (2018) Compatibility of entomopathogenic fungi and botanical extracts against the wheat aphid, Sitobion avenae (Fab.) (Hemiptera:Aphididae). Egypt J Biol Pest Co 28:97. https://doi.org/10.1186/s41938-018-0101-9

Araújo JPM, Hughes DP (2016) Diversity of Entomopathogenic Fungi: Which Groups Conquered the Insect Body? Adv Genet 94. https://doi.org/10.1016/ bs.adgen.2016.01.001

Asawalam EF, Emosairue SO, Ekeleme F, Wokocha RC (2007) Insecticidal effects of powdered parts of eight Nigerian plant species against maize weevil Sitophilus zeamais Motschulsky (Coleoptera: Curculionidae). Elec J Env Agric Food Chem 11:2526-2533

Athanassiou CG, Palyvos NE (2006) Laboratory evaluation of two diatomaceous earth formulations against Blattisocius keegani Fox (Mesostigmata: Ascidae) and Cheyletus malaccensis (Oudemans) (Prostigmata: Cheyletidae). Biol Control 38:350-355

Bosly H, Kawanna M (2012) Fungi species and red flour beetle in stored wheat flour under Jazan region conditions. Toxicol Ind Health 30(4). https://doi.org/ $10.1177 / 0748233712457449$

Buckman KA, Campbell JF, Bhadriraju S (2013) Tribolium castaneum (Coleoptera: Tenebrionidae) Associated With Rice Mills: Fumigation Efficacy and Population Rebound. J Econ Entomol 1:499-512

Campbell JF, Runnion C (2003) Patch exploitation by female red flour beetles, Tribolium castaneum. J Insect Sci 3:1-8

Castiglioni E, Vendramin JD, Alves SB (2003) Compatibility between Beauveria bassiana and Metarhizium anisopliae with Nimkol-L in the control of Heterotermes tenuis. Man Integr Plagas Agroecol 69:38-44

Chadda IC (2016) Fumigation with phosphine - a perspective. Indian. J Entomol 78 (special):3. https://doi.org/10.5958/0974-8172.2016.00023.7

Furlong MJ, Groden E (2003) Starvation induced stress and the susceptibility of the Colorado potato beetle, Leptinotarsa decemlineata, to infection by Beauveria bassiana. J Invertebr Pathol 83:127-138

Hanif MS, Hasan M, Sagheer M, Aatif HM, Malik R, Waqas M (2016) Insecticidal activity of different botanicals (bitterapple, neem and tobacco) towards Tribolium castaneum (Coleoptera: Tenebrionidae). J Glob Innov Agric Soc Sci 4:197-203

Haraprasad N, Niranjana SR, Prakash HS, Shetty HS, Wahab S (2001) Beauveria bassiana, a potential mycopesticide for the efficient control of coVee berry borer, Hypothenemus hampei (Ferrari) in India. Biocontrol Sci Technol 11:251-260

Hyde KD, Xu J, Stadler M (2019) The amazing potential of fungi: 50 ways we can exploit fungi industrially. Fungal Divers 97:1-136

Inglis GD, Goettel MS, Butt TM, Hermann S (2001) Use of Hyphomycetous fungi for managing insect pests. In: Butt TM (ed) Fungi as Biocontrol Agents: Progress, Problems and Potential. GBR CABI Publishing, Wallingford, Oxon, p 23

Islam MS, Talukder FA (2005) Toxic and residual effects of Azadirachta indica, Tagetes erecta and Cynodon dactylon seed extracts and leaf powders towards Tribolium castaneum. J Plant Dis Protect 6:594-601

Kavallieratos NG, Athanassiou CG, Michalaki MP, Batta YA, Rigatos HA, Pashalidou FG, Balotis GN, Tomanovic Z, Vayias BJ (2006) Effect of the combined use of Metarhizium anisopliae (Metschnikoff) Sorokin and diatomaceous earth for the control of three stored-product beetle species. Crop Prot 10:1087-1094 
Khashaveh A, Ghosta Y, Safarlizadeh MH, Ziaee M (2011) The Use of Entomopathogenic Fungus, Beauveria bassiana (Bals.) Vuill. in assays with Storage Grain Beetles. J Agric Sci Tech Iran 13:35-43

Lord JC (2007) Enhanced efficacy of Beauveria bassiana for the red flour beetle, Tribolium castaneum with reduced moisture. J Econ Entomol 100:171-175

Mullin CA (1988) Adaptive relationships of epoxide hydrolase in herbivorous arthropods. J Chem Ecol 14:1867-1888

Nboyine JA, Asante SK, Nutsugah SK, Abudulai M, Agyapong FA, Luke B, Clottey V (2015) Biological control of the larger grain borer, Prostephanus truncatus (Horn) in stored maize using the fungal pathogen, Beauveria bassiana and the predator Teretrius nigrescens (Lewis). J Stored Prod Res 4:30-37

Negahban M, Moharramipoura S, Sefidkon F (2007) Fumigant toxicity of essential oil from Artemisia sieberi besser against three stored-product insects. J Stored Prod Res 43:123-128

Pimentel MAG, Faroni LRDA, Silva FH, Batista MD, Guedes RNC (2010) Spread of phosphine resistance among Brazilian populations of three species of stored product insects. Neotrop Entomol 39:101-107

Purwar JP, Sachan GC (2006) Synergistic effect of entomogenous fungi on some insecticides against Bihar hairy caterpillar, Spilarctia obliqua (Lepidoptera: Arctiidae). Microbiol Res 161:38-42

Rajendran S, Sriranjini V (2008) Plant products as fumigants for stored-product insect control. J Stored Prod Res 44:126-135

Rehman H, Hasan H, Ali Q, Yasir M, Saleem S, Mirza S, Shakir HU, Ali AM, Ahmed HM (2018) Potential of three indigenous plants extracts for the control of $T$. castaneum (Herbst) and R. dominica (Fab.). Pak Entomol 1:31-37

Riasat T, Wakil W, Ashfaq M, Sahi ST (2011) Effect of Beauveria bassiana mixed with diatomaceous earth on mortality, mycoses and sporulation of Rhyzopertha dominica on stored wheat. Phytoparasitica 39:325-331

Sarwar M (2015) Categorization of some advanced local wheat lines against Tribolium castaneum (Herbst) (Coleoptera: Tenebrionidae). Int J Life Sci Eng 3 108-113

Tefera T, Pringle KL (2003) Food consumption by Chilo partellus (Lepidoptera: Pyralidae) larvae infected with Beauveria bassiana and Metarhizium anisopliae and effects of feeding natural versus artificial diets on mortality and mycosis. J Invertebr Pathol 84:220-225

Vassilakos TN, Athanassiou CG, Kavallieratos NG, Vayias BJ (2006) Influence of temperature on the insecticidal effect of Beauveria bassiana in combination with diatomaceous earth against Rhyzopertha dominica and Sitophilus oryzae on stored wheat. Biol Control 2:270-281

Wood SN, Thomas MB (1996) Space, time and persistence of virulent pathogens. Pro R Soc Lond Biol Sci 263:673-680

Wraight SP, Ramos ME (2005) Synergistic interaction between Beauveria bassiana and Bacillus thuringiensis tenebrionis-based bio-pesticides applied against field populations of Colorado potato beetle larvae. J Invertebr Pathol 90:139-150

Zettler JA, Arthur FH (2000) Chemical control of stored product insects with fumigants and residual treatments. Crop Prot 19:577-582

\section{Publisher's Note}

Springer Nature remains neutral with regard to jurisdictional claims in published maps and institutional affiliations.

\section{Submit your manuscript to a SpringerOpen ${ }^{\circ}$ journal and benefit from:}

- Convenient online submission

- Rigorous peer review

- Open access: articles freely available online

- High visibility within the field

- Retaining the copyright to your article

Submit your next manuscript at $\boldsymbol{\nabla}$ springeropen.com 